\title{
Progesterone Receptor Positive by Immunohistochemistry 1-10 Percent
}

National Cancer Institute

\section{Source}

National Cancer Institute. Progesterone Receptor Positive by Immunohistochemistry 1-

10 Percent. NCI Thesaurus. Code C141448.

An immunohistochemical staining finding indicating that 1-10 percent of the cells in a tissue sample are expressing progesterone receptor. 